\author{
ks. Janusz Stańczuk ${ }^{1}$ \\ 0000-0001-8888-6114
}

Papieski Wydział Teologiczny w Warszawie - Collegium Joanneum

\title{
Ksiądz Stanisław Piotrowski, apostoł Kalisza
}

Ksiądz Stanisław Piotrowski (1912-1998) przez niemal połowę kapłańskiego życia był związany z Kaliszem. Tam znajduje się jego grób, ulica nazwana jego imieniem oraz kilka pamiątkowych tablic i epitafiów. Jego postać nadal inspiruje mieszkańców Kalisza. Stąd uzasadniony jest tytuł apostoła tego miasta. Jednak jego dokonania pastoralne znacznie przekraczają granicę miasta oraz epokę naznaczoną datami narodzin i śmierci.

Urodził się 1 listopada 1912 roku w Białych Szczepanowicach, w parafii Czyżew (obecnie diecezja łomżyńska), ukończył seminarium we Włocławku i przyjął święcenia kapłańskie 17 grudnia 1938 roku. Na mapie jego posługi znalazły się głównie: Włocławek (od święceń do $1959 \mathrm{r}$. z przerwami), Warszawa (1941-1945), Kazimierz Biskupi (1960-1965), Turek (1963-1965), Koło (1965-1971) i wreszcie Kalisz (1959 r., potem od 1971 r. do śmierci w 1998 r.). Był także więźniem obozu w Stutthofie

1 Kapłan arch. warszawskiej, absolwent Uniwersytetu Kardynała Stefana Wyszyńskiego w Warszawie (teologia pastoralna), wykładowca Papieskiego Wydziału Teologicznego w Warszawie, redaktor naukowy Warszawskich Studiów Teologicznych, autor homilii i książek dla dzieci, red. naczelny miesięcznika „Tak Rodzinie”; adres e-mail: stanczuk@pwtw.pl. 
i stalinowskiego więzienia w Bydgoszczy². Pełnił funkcje: prefekta, kapelana (również wojennego), instruktora harcerskiego, spowiednika, wizytatora, pracownika różnych referatów kurialnych i sądu biskupiego, katechety i wykładowcy, redaktora, proboszcza i dziekana. W czasie niemal 60 lat kapłańskiej posługi nigdy nie zajmował stanowiska wikariusza ${ }^{3}$.

Przez większość życia ks. Piotrowski poruszał się na pograniczu dwóch rzeczywistości - teologicznej refleksji związanej z opisaniem sytuacji Kościoła oraz praktycznego duszpasterstwa, realizowanego głównie w środowisku dyktatury hitlerowskiej i komunistycznej, a częściowo tylko w wolnej Polsce. Można go nazwać prekursorem współczesnego pojmowania teologii pastoralnej. Ksiądz biskup Kazimierz Majdański określił go mianem najgorliwszego duszpasterza, z jakim miał okazję zetknąć się w swoim życiư . Również wspomnienia innych biskupów, kapłanów i osób świeckich rysują sylwetkę aktywnego, pomysłowego i oddanego Bogu kapłana, którego innowacjami interesował się także Jan Paweł II ${ }^{5}$.

Głównym zadaniem artykułu będzie ukazanie teologicznej i duszpasterskiej intuicji ks. Piotrowskiego, zdefiniowanej formalnie przez papieża Jana XXIII pod pojęciem znaków czasu' ${ }^{6}$. Papież postulował już na pierwszych spotkaniach Soboru Watykańskiego II, aby wypracować nowe metody i formy głoszenia Ewangelii, uwzględniając pozytywne i negatywne aspekty rozwoju cywilizacji. Z tego powodu liczne dokumenty soborowe zachęcają kapłanów do roztropnego rozpoznawania rzeczywistości ${ }^{7}$. Wielu polskich duszpasterzy, wykazując się gorliwą posługą,

2 J. Bąk, Piotrowski Stanisław, w: Leksykon duchowieństwa represjonowanego w PRL w latach 1945-1989, t. 2, red. J. Myszor, Warszawa 2003, s. 221-222.

3 A. Poniński, Piotrowski Stanisław, w: Słownik polskich teologów katolickich 1995-2003, t. 9 , red. J. Mandziuk, Warszawa 2006, s. 497-500. Słownik podaje skróconą biografię oraz niemal kompletną bibliografię wszystkich pism ks. Piotrowskiego.

4 K. Majdański bp, Życie - jak szarża ułańska, w: Służył w prostocie i miłości: księga pamiątkowa ku czci ks. Stanisława Piotrowskiego (1912-1998), red. S. Olejnik, J. Plota, Kalisz 2003, s. 124.

5 H. Muszyński bp, Jeden z najbardziej niezwykłych ludzi, których spotkałem, w: Stużył w prostocie i miłości: księga pamiątkowa ku czci ks. Stanisława Piotrowskiego (1912-1998), Kalisz 2003, s. 125.

6 S. Bielecki, Znaki czasu i ich rozpoznawanie, w: Teologia pastoralna, t. 1, red. R. Kamiński, Lublin 2006, s. 228.

7 Por. Konstytucja duszpasterska o Kościele w świecie współczesnym Gaudium et spes, 44 . 
nadal poszukuje rozsądnego rozeznania potrzeb i zagrożeń, z jakimi musi mierzyć się współczesny Kościół. Część tych postulatów w dość profetyczny sposób zostało nakreślonych w pismach i działaniach ks. Piotrowskiego, co więcej - nie straciły swej aktualności. Niniejszy artykuł będzie więc nie tylko przypomnieniem dokonań tego kapłana, ale także próbą wydobycia - w kluczu teologii „znaków czasu” - najważniejszych i ciągle obligujących kierunków duszpasterstwa.

\section{Wśród dzieci i młodzieży}

W porządku chronologicznym pierwszym i najważniejszym z zainteresowań ks. Piotrowskiego stała się praca wychowawcza z dziećmi i młodzieżą. W okresie dorastania doświadczył nieobecności ojca, który na 10 lat wyjechał w celach zarobkowych do USA. Być może ten fakt, w połączeniu z fascynacją ruchem harcerskim, ukazał młodemu kapłanowi potrzebę towarzyszenia młodym ludziom w procesie wzrastania, kształtowania moralności i podejmowania życiowych decyzji. Podobną mentalnością pedagogiczną charakteryzował się - młodszy o osiem lat - późniejszy biskup krakowski Karol Wojtyła, z którym ks. Piotrowski spotykał się w latach 60. przy okazji prac w komisjach episkopatu.

Pierwszym dowodem zainteresowana specjalizacją pedagogiczną jest temat pracy dyplomowej, którą każdy z alumnów musiał napisać pod koniec studiów seminaryjnych. We Włocławku w latach 1937- 1938 studia ukończyło ogółem 39 alumnów. Większość opracowań miała charakter monografii teologicznych i historycznych. Zaledwie dwa teksty dotyczyły „nowinkarskich” jeszcze podówczas zagadnień z zakresu pedagogiki religijnej. Ksiądz Piotrowski swoją niezachowaną, niestety, do dnia dzisiejszego dysertację zatytułował: Indywidualizacja w wychowaniu a wiek młodzieży. Doceniając te zainteresowania młodego kapłana, władze diecezji bezpośrednio po święceniach mianowały go prefektem w Niższym Seminarium Duchownym im. Piusa X we Włocławku oraz kierownikiem internatu.

8 J. Stańczuk, Stanisław Piotrowski. Kapłan- harcerz - wychowawca, Warszawa 2013, s. 38. 
Pracę z młodzieżą kontynuował także w okresie okupacji. Po ucieczce z obozu w Stutthofie ukrywał się pod przybranym nazwiskiem w Warszawie. Podjął obowiązki wychowawcy w kilku bursach, brał udział w tajnym nauczaniu, w organizacji rekolekcji, współpracował z podziemnym harcerstwem i przeszedł kurs instruktorski w stopniu podharcmistrza. Wiele uwagi poświęcał nauczaniu moralnemu i społecznemu dla młodzieży. Chociaż w pewnym zakresie wspomagał - jako kapelan - młodzież uczestniczącą w konspiracji, zdawał sobie sprawę, że walka zbrojna jest tylko jednym z elementów trwania narodu. Pragnął przygotować młodzież do podjęcia w dorosłym życiu dojrzałych funkcji społecznych, rodzinnych i religijnych ${ }^{9}$.

Ustrój komunistyczny, kontrolujący po wojnie niemal wszystkie dziedziny życia społecznego, znacznie utrudniał pracę katechetyczną i wychowawczą Kościoła w Polsce. Ksiądz Piotrowski przez krótki czas powrócił do obowiązków prefekta i wychowawcy, także przez niespełna rok zajmował stanowisko komendanta hufca harcerskiego we Włocławku. Obarczono go w latach pięćdziesiątych licznymi funkcjami kurialnymi i diecezjalnymi. W latach 1950-1953 kierował diecezjalnym tygodnikiem „Ład Boży”, który był przeznaczony dla rodzin katolickich, a założony po wojnie przez ks. Stefana Wyszyńskiego. Troszczył się, aby każdy numer periodyku zawierał materiały przeznaczone dla dzieci i młodzieży oraz dla rodziców. Niektóre z tekstów wyszły spod pióra redaktora naczelnego, chociaż dokładne autorstwo wielu materiałów jest dzisiaj trudne do sprecyzowania ze względu na często używane pseudonimy. Część z nich udało się jednak zidentyfikować i przypisać ks. Piotrowskiemu. Omawia w nich dylematy moralne, treści katechizmowe, pokazuje wpływ wiary na decyzje człowieka. W 1953 roku pismo zostało zamknięte $\mathrm{w}$ ramach represji po śmierci Stalina ${ }^{10}$.

9 S. Piotrowski, Zerwane okowy, Kalisz 1998, s. 117-137. W okupowanej Warszawie ks. Piotrowski podjął m.in. pracę opiekuna w bursie przy ul. Senatorskiej 28/30, prowadzonej przez Radę Główną Opiekuńczą, w bursie przy ul. Widok 7 oraz funkcję kapelana Sióstr Rodziny Maryi przy ul. Hożej 53. Siostry zasłynęły ratowaniem setek dzieci z żydowskich rodzin Warszawy. Również w tej pracy uczestniczył ks. Piotrowski, chociaż ze względu na konspirację nie zachowały się szczegółowe zapiski na ten temat (S. Piotrowski, Zerwane okowy, dz. cyt., s. 117-137).

10 K. Rulka, J. Ludwiczak, Publikacje ks. Stanisława Piotrowskiego, w: Służył w prostocie i miłości. Księga pamiątkowa ku czci ks. Stanisława Piotrowskiego (1912-1998), red. S. Olejnik, J. Plota, 
Maszyna do pisania, jako podstawowe w tamtym czasie narzędzie publikacji, towarzyszyła ks. Piotrowskiemu w wielu innych inicjatywach wychowawczych i katechetycznych. Spośród nich warto wymienić przynajmniej dwa dzieła, które szczęśliwie przetrwały do naszych czasów w postaci maszynopisu. Pierwsze z nich to Wandzia Brodzikowska - zbiór wspomnień o życiu i śmierci tytułowej Wandzi, mieszkanki Włocławka, która zmarła w wielu 14 lat na początku 1939 roku w opinii jeśli nie świętości - to przynajmniej szlachetnego i pobożnego życia ${ }^{11}$. Maszynopis powstał w 1952 roku. W dwudziestoleciu międzywojennym kult świętych dzieci zyskiwał w Kościele wielu zwolenników. Objawienia w Lourdes, Gietrzwałdzie, Fatimie i innych miejscach pokazywały, że Bóg poprzez dzieci kieruje do świata swoje posłannictwo. Niestety, po drugiej wojnie światowej kult świętych dzieci, zwłaszcza męczenników, w obliczu śmierci milionów niewinnych istot, został znacznie ograniczony. Tym bardziej należy docenić wysiłek, jaki ks. Piotrowski włożył w ocalanie pamięci o Wandzie Brodzikowskiej. Można powiedzieć, że również w tym zakresie o kilkadziesiąt lat wyprzedził nauczanie Kościoła, w którym pod koniec XX wieku powrócono do tematu beatyfikacji małych męczenników, ofiar różnego rodzaju rewolucji i prześladowań w różnych częściach świata.

Drugim dużym dokumentem dedykowanym młodemu pokoleniu są Przemówienia dla dzieci zredagowane ok. 1963 roku. Publikacja zawiera 97 kazań, które pokazują wielki talent i zaangażowanie ks. Piotrowskiego w homiletykę dziecięcą. Przemówienia są bardzo zróżnicowane pod względem tematycznym, chociaż większość z nich dotyczy problemów powiązanych z rokiem liturgicznym albo z wyjaśnieniem prawd

Kalisz 2003, s. 104-113. Publikacja zawiera wykaz wszystkich materiałów autorstwa ks. Piotrowskiego, które były znane w momencie ukazania się tej książki. Kilka innych tekstów odnaleziono w późniejszych latach.

11 S. Piotrowski, Wandzia Brodzikowska, Włocławek 1952 [100 s.; Mps ilustr. w Bibliotece Seminarium Włocławskiego (BSWł.), sygn.: M 96]. Maszynopis powstał w niewielkiej ilości egzemplarzy, autorowi artykułu wiadomo o dwóch zachowanych pozycjach: w Bibliotece Seminarium we Włocławku oraz w rękach rodziny p. Brodzikowskich w Gdańsku. W 2008 r. udało się opublikować książkę w nakładzie kilkuset egzemplarzy pod nieco zmienionym tytułem: Byliście rodzicami świętego dziecka. Historia Wandzi Brodzikowskiej z Włocławka, Warszawa 2008 (przyp. aut). 
katechizmowych. Do dzisiaj w wielu kościołach Polski, a tym bardziej Europy, msza z udziałem dzieci pozostaje dla licznych rodzin ostatnim elementem łączącym je z parafią. Obliguje to duszpasterzy do starannego przemyślenia kilku kwestii, o których mówi, chociażby późniejsze o 10 lat od publikacji ks. Piotrowskiego, watykańskie Dyrektorium o mszach świętych z udziałem dzieci (Rzym 1973). Wypada docenić intuicję i dorobek ks. Piotrowskiego, który zdawał sobie sprawę z konieczności dobrego przygotowania mszy dla dzieci, a także z szeroko pojętej potrzeby edukacji kulturowej i literackiej najmłodszego pokolenia.

Oprócz bardzo intensywnej i regularnej pracy katechetycznej oraz parafialnej z dziećmi i młodzieżą (służba liturgiczna, Ruch Światło-Życie, pielgrzymki itp.) ks. Piotrowski nieustannie poszukiwał dodatkowych form, które wspomagały rozwój fizyczny, intelektualny, społeczny i religijny młodego pokolenia. Często przekraczał kanon inicjatyw typowo pastoralnych, ale dzięki temu szybko stał się przyjacielem i autorytetem dla młodzieży. W latach powojennych kupił dużą łódź rzeczną z motorem i żaglem. Służyła do organizowania harcerskich (i nie tylko) rejsów po Wiśle. Na werandzie plebanii założył hodowlę jedwabników. Młodzież zbierała w okolicy liście morwy. Dochód ze sprzedaży zasilał kasę wycieczkową i pielgrzymkową. W czasie plagi stonki zamiast prowadzić katechezę w salce parafialnej zorganizował akcję zbierania owadów do butelek (popularna wówczas metoda), aby wspomóc rolników w walce ze szkodnikiem. Była to lekcja religii połączona z praktyką miłosierdzia. W parafii w Kole zakupił dęte instrumenty muzyczne i zorganizował młodzieżową orkiestrę. Zaprosił także pięć zespołów na pierwszy w diecezji mini Sacrosong muzyczny. Każde niemal wakacje spędzał z młodzieżą, dziećmi lub klerykami na obozach stacjonarnych i wędrownych. To tylko przykładowe inicjatywy, które ks. Piotrowski podejmował wobec młodego pokolenia, cały czas prowadząc normalną pracę kurialną, a potem duszpasterską w parafiach. 


\section{Siła rodziny}

Olbrzymi wysiłek włożony w pracę duszpasterską z młodzieżą motywowany był przekonaniem o konieczności wspierania rodziny, która z powodów moralnych lub ekonomicznych często traciła swoją funkcję wychowawczą. Uwidoczniło się to szczególnie po drugiej wojnie światowej, w okresie ideologicznej ekspansji komunizmu. Wiele pastoralnej inicjatywy należało skierować na towarzyszenie rodzinie i na wzmocnienie wspólnego frontu wychowawczego.

W niniejszym artykule była już mowa o funkcji redaktora naczelnego w „Ładzie Bożym”, czasopiśmie archidiecezji włocławskiej. Pismo założył ks. Stefan Wyszyński i przewodził mu przez pierwszych 27 numerów. Periodyk z założenia miał unikać bieżącej polityki, koncentrować się natomiast na tematyce rodzinnej i społecznej. Wybór ks. Piotrowskiego na jednego z kolejnych redaktorów naczelnych świadczy pośrednio o jego zaangażowaniu w duszpasterstwo rodzin.

$\mathrm{Z}$ tego samego okresu pochodzi opracowanie Zagadnienia duszpasterskie (Włocławek 1953), w którym autor mocno postuluje wprowadzenie na terenie diecezji tzw. katechezy zsynchronizowanej. Idea tej katechezy polegała na wygłaszaniu w kościołach całej Polski homilii na jeden temat, dla wszystkich poziomów wiekowych, a później pogłębienie tematu w katechezie szkolnej, parafialnej i rodzinnej. Pomysł ten był

twórczą i szczęśliwą próbą organicznego połączenia katechezy dla dzieci, problemów dla młodzieży i materiałów dla rodziców z niedzielną liturgią, tworząc katechezę parafialną i wspólnotową. Sformułowania w nich zawarte posługiwały się językiem powszechnej w tym czasie teologii neoscholastycznej ${ }^{12}$.

Chociaż stosowano go w Polsce zaledwie w latach 1952-1956, to jednak pewne postulaty współpracy wychowawczej między parafią a rodziną pozostały już na zawsze obecne w polskiej katechetyce.

Dobrze udokumentowane jest zaangażowanie ks. Piotrowskiego w prawidłowe przygotowanie narzeczonych do zawarcia związku małżeńskiego

\footnotetext{
12 J. Charytański, Zmagania o kształt katechezy w Polsce. Długa wspólna droga, Kraków 2001, s. 16
} 
i założenia rodziny. Z powodu braku polskich źródeł naukowych często wykorzystywał literaturę teologiczną obszaru języka niemieckiego. Do osób, które miały wpływ na ukształtowanie jego poglądów należeli m.in.: Zdana Brandt - lekarz pediatra, ks. Kazimierz Majdański - redaktor „Ateneum Kapłańskiego” oraz jego brat Walenty Majdański, znany publicysta katolicki ${ }^{13}$. Ksiądz Piotrowski postulował włączenie do procesu przygotowania nie tylko kapłanów (także spoza parafii), ale również prawników, położne i lekarzy ${ }^{14}$. Założenia te, oczywiste w dzisiejszej katechezie przedślubnej, w latach 50. i 60. ubiegłego wieku dopiero zdobywały swoich zwolenników. W latach 1956-1959 kierował we Włocławku Wydziałem Duszpasterskim. W tym czasie powstało tam jedno z pierwszych w Polsce diecezjalnych duszpasterstw rodziny. W późniejszej serii artykułów w „Ateneum Kapłańskim” wskazywał na konieczną obecność kapłana w przeżywaniu razem z rodzinami życia duchowego i sakramentalnego, ale jednocześnie obligował Kościół do pozostawienia innych problemów (medycznych, higienicznych, jurydycznych) w rękach kompetentnych osób świeckich. Jednym z potrzebnych, do dziś nie do końca chyba zrealizowanych, postulatów była potrzeba utworzenia w każdym dekanacie aktywnie działającej poradni życia małżeńskiego ${ }^{15}$. Zachęcał laikat do szkolenia w zakresie doradztwa rodzinnego i rozwinął potem w Kaliszu jedną z pierwszych w kraju Poradnię Życia Rodzinnego ${ }^{16}$.

Dzięki staraniom ks. prof. Majdańskiego i przy poparciu ks. prof. Karola Wojtyły powstał we Włocławku zespół do spraw katechizacji o rodzinie. Do udziału w nim zapraszano znanych moralistów, teologów,

13 S. Piotrowski, Jak gotyckie katedry, w: Facere voluntatem Tuam. Księga Jubileuszowa ku czci ks. arcybiskupa K. Majdańskiego, red. J. A. Kłys i in., Szczecin 1995, s. 175-176.

${ }_{14}$ S. Piotrowski, Duszpasterz i duszpasterstwo, t. 1-2, Włocławek 1956-1958 [-325, 93 s.; 29 cm. Mps w BSWł, sygn.: W 50], s. 170-183. Ksiądz Piotrowski pisze: „Oszołomieni powodzeniem i przyzwyczajeni do masowego duszpasterstwa nieraz sobie lekceważymy oddziaływanie na jednostkę przypadkowo spotkaną i na jednostkę, która z uwagi na szczególną rolę w społeczeństwie zasługiwać powinna na troskliwą duszpasterską opiekę. Chodzi tu o lekarza i o położną (...) Niewiele pomoże kancelaria i konfesjonał, jeżeli gabinet lekarza i praca położnej będą prowadzić antychrześcijańską dywersję" (S. Piotrowski Duszpasterz i duszpasterstwo, t. 1-2, dz. cyt., s. 179-180).

15 S. Piotrowski, Poradnictwo parafialne dla małżeństw, „Ateneum Kapłańskie” 50/56 (1958) z. 2(295), s. 248-257.

16 J. Plota, Duszpasterz, w: Służył w prostocie i miłości..., dz. cyt., s. 68. 
duszpasterzy, a także lekarzy, m.in. dr. Fijałkowskiego i dr. Święcickiego. Opracowane przez nich materiały stały się kanwą duszpasterstwa rodzin dla wielu diecezji w Polsce. Wśród osób zaangażowanych w to dzieło należy wymienić także ks. Piotrowskiego, który dodatkowo w latach 1966-1975 pełnił funkcję diecezjalnego duszpasterza rodzin ${ }^{17}$.

Troskę ks. Piotrowskiego o duszpasterstwo rodzin można podsumować, ukazując dwa fakty z początków i z końca jego aktywności w tym obszarze pracy pastoralnej. W 1955 roku służba bezpieczeństwa aresztowała go i osadziła na pół roku w stalinowskim więzieniu w Bydgoszczy. Bezpośrednim powodem uwięzienia było drukowanie materiałów poświęconych przygotowaniu do małżeństwa w broszurce Walentego Majdańskiego Pamiętnik narzeczonych ${ }^{18}$. Świadczy to pośrednio o dużym zaangażowaniu ks. Piotrowskiego w walkę o wytrącenie komunistycznej propagandzie monopolu na kształtowanie modelu rodziny. Drugim natomiast dowodem nieustającej aktywności są wydarzenia z lat emerytalnych (po 1987 r.). Podjął się wówczas w okresie wakacyjnym posługi w odradzających się parafiach na Podolu, które leży na Ukrainie. Widząc upadek etosu życia rodzinnego w byłych krajach sowieckich, w maju 1990 roku prosił biskupa włocławskiego o umożliwienie wyjazdu na Ukrainę ekipie złożonej z kapłana i dwóch kompetentnych osób świeckich, dzięki którym udałoby się zrealizować dla tamtejszego Kościoła kurs poradnictwa rodzinnego ${ }^{19}$.

W tej dziedzinie duszpasterstwa ks. Stanisław Piotrowski zapisał się jako wytrwały nauczyciel Kościoła, zachęcający swoją przenikliwością i gorliwością do duszpasterskiej troski o chrześcijański model życia małżeńskiego i rodzinnego.

17 S. Piotrowski, W stużbie, Kalisz 1998, s. 95-96.

18 S. Piotrowski, W służbie, dz. cyt., s.74.

19 Por. S. Piotrowski, Na drodze nowej ewangelizacji, dz. cyt. 


\section{Bóg objawiony przez kulturę}

Wzajemne przenikanie się świata religii oraz kultury (sztuki) jest zjawiskiem tak dawnym, że trudno dzisiaj odseparować wspólne początki. Część uczonych wychodzi z założenia, że religia stała się źródłem i siłą rozwojową każdej cywilizacji ${ }^{20}$. Jednak wielu filozofów o pochodzeniu chrześcijańskim (n.p. J. Maritain, J. Daniélou) skłania się ku tezie, iż religia przerasta wszelkie granice kultur i cywilizacji, jako zjawisko transcendentne i niezależne od poglądów poszczególnych grup ludzkości. Można więc mówić w określonych warunkach wyłącznie o kulturze inspirowanej wartościami chrześcijańskimi.

Współistnienie kultury i religii zostało zantagonizowane w epoce oświecenia ${ }^{21}$. Prace niektórych filozofów (Augusta Comte'a, Fryderyka Nietzschego, Karola Marksa i Fryderyka Engelsa) oraz francuskich encyklopedystów skierowały cywilizację europejską w stronę humanizmu antropocentrycznego, który zanegował Objawienie i zdetronizował wartości chrześcijańskie jako uniwersalny i personalistyczny motyw sztuki ${ }^{22}$. Można powiedzieć, że ten sztucznie wywołany konflikt mocno zapisał się w kulturze europejskiej i do dzisiaj determinuje poczynania wielu twórców. Odzyskiwanie kultury dla Ewangelii było i jest jednym z wyzwań, przed którym stoi Kościół XXI wieku. Wizja ta została dość stanowczo nakreślona w drugim rozdziale Konstytucji duszpasterskiej o Kościele w świecie współczesnym Gaudium et spes na Soborze Watykańskim II.

Ksiądz Stanisław Piotrowski dość wcześnie zrozumiał, iż szeroko rozumiana kultura i sztuka jest niezbędnym czynnikiem prawidłowo

20 Por. Ch. Dawson, Religia i kultura, J. W. Zielińska, Warszawa 1959, s. 22.

${ }^{21}$ Jest to stwierdzenie o charakterze ogólnym, bowiem nie wszystkie rodzaje sztuki były w historii Kościoła wykorzystywane w jednakowych stopniu. Spośród różnych dziedzin Kościół najpierw zaakceptował słowo (literaturę), a częściowo także obraz i rzeźbę oraz muzykę. Negatywnie odnoszono się w pierwszym tysiącleciu n.p. do widowisk teatralnych (por. B. Dutkiewicz, Wartości „sacrum” a problemy ekspresji muzyczno-ruchowej, w: Sacrum - sztuka - wychowanie, red. W. A. Sacher, Kraków 2006, s. 168-170).

22 J. Maritain, Humanizm integralny. Zagadnienia doczesne i duchowe nowego świata chrześcijańskiego, Warszawa 1981, s. 27-28 
funkcjonującego duszpasterstwa i wychowania ${ }^{23}$. W poprzednich punktach poruszone zostały przykłady jego osobistego zaangażowania w twórczość literacką i publicystyczną. Z uwagi na blokady związane z komunistyczną cenzurą wiele jego artykułów i książek ukazywało się w ograniczonej formie lub wyłącznie w tzw. drugim obiegu, czasem zaledwie w nakładzie kilku egzemplarzy (maszynopisy). Jego osobiste opracowania i wspomnienia prezentują różny poziom literacki i językowy, czasem są tylko kronikarskim świadectwem epoki i ludzi w niej żyjących. Z pewnością w katechezie starał się zainteresować swoich uczniów i parafian lekturą literatury pięknej i chrześcijańskiej. Początki jego współpracy z „Ateneum Kapłańskim” pod koniec lat 40 . XX wieku wiązały się $\mathrm{z}$ opracowaniem recenzji (połączonej z zachętą do czytania) na temat książek dla młodzieży. Umiejętnie wykorzystywał cytaty literackie w homiliach, katechezach, wystąpieniach. Starał się aktywnie o zakładanie parafialnych bibliotek ${ }^{24}$.

Animacje kulturalne ks. Piotrowskiego nie ograniczały się do świata literatury. W wielu innych dziedzinach przyjął dla siebie rolę mecenasa, inspiratora, czasami współtwórcy różnych form scenicznych, muzycznych czy wystawowych. W pamięci współpracowników i parafian najbardziej zapisały się szczególnie trzy obszary aktywności kulturowej: festiwale muzyczne, Dni Kultury Chrześcijańskiej oraz spektakle sceniczno-teatralne.

Szybki rozwój muzyki popularnej, zwłaszcza w połowie XX wieku, dla niektórych duszpasterzy (nielicznych, niestety) stał się inspiracją

${ }^{23}$ W czasie wojny ks. Piotrowski stracił m.in. swój prywatny księgozbiór teologiczno-pedagogiczny, szacowany na ok. 400 pozycji. Z dzisiejszego punktu widzenia nie była to być może wielka biblioteka, należy jednakże pamiętać, że w chwili wybuchu wojny ks. prefekt miał za sobą niespełna 10 miesięcy kapłaństwa, a książki były relatywnie kosztowne. Posiadanie takiej biblioteki świadczy więc o dużym zainteresowaniu literaturą piękną, teologiczną i pedagogiczną (por. W. Frątczak, Diecezja włocławska w okresie II wojny światowej, Włocławek 2008, s. 337).

${ }_{24}$ Zob. S. Piotrowski, Duszpasterz i duszpasterstwo, dz. cyt., s. 31. Ksiądz Piotrowski apeluje do księży o użyczanie wiernym książek ze swoich domowych i parafialnych bibliotek. Pisze: „Dziś, wobec kurczenia się wachlarza środków duszpasterzowania, należy sobie przy każdej okazji pomagać dobrą książką (...). Książki nie mogą leżeć w szafie (...). Książki katolickie mogą pełnić ruchliwą służbę (...)”. 
do dwutorowego traktowania kultury muzycznej. Zrozumieli, że muzyka chrześcijańska nie może zamykać się w obszarze funkcji liturgicznej, ale musi także współdziałać z procesem ewangelizacji i kształtować mentalność religijną całego pokolenia, a zwłaszcza dzieci i młodzieży. W 1969 roku w Łodzi odbył się pierwszy Sacrosong - wielki festiwal młodej muzyki chrześcijańskiej. Towarzyszyły mu utrudnienia ze strony władz komunistycznych, a także niezrozumienie dużej części hierarchii kościelnej. Ideę festiwalu uratował swoim autorytetem kard. Karol Wojtyła ${ }^{25}$.

Ksiądz Piotrowski, jako proboszcz parafii Koło (1965-1971), wkrótce zorganizował podobny mini festiwal w diecezji włocławskiej ${ }^{26}$. W parafii św. Mikołaja w Kaliszu wspierał młodzieżowy zespół Mosty, który zdobył trzecią nagrodę na Sacrosongu w Lublinie w 1976 roku za piosenkę o tym samym tytule. Dzięki temu kolejny festiwal mógł odbyć się w 1977 roku w Kaliszu. Sceny użyczyło kilka kaliskich kościołów, które na czas koncertów były wypełnione po brzegi ludźmi zafascynowanymi religijną muzyką popularną. Koncertom towarzyszyła dość szeroka, jak na owe czasy, akcja reklamowa i promocyjna. Życzenia przysłali m.in. Ojciec Święty, ksiądz prymas i kard. Wojtyła. Władze miasta uniemożliwiły prowadzenie koncertu plenerowego. Mimo to festiwal okazał się jednym z najgłośniejszych wydarzeń kulturowych w życiu Kalisza. Zespół Mosty, cieszący się nieustannym wsparciem ks. Piotrowskiego, występował jeszcze wiele razy na scenach w rodzinnym mieście i w całej Polsce ${ }^{27}$.

Animacja muzyczna była wielką troską ks. Piotrowskiego w czasie katechezy (nie dysponując zbyt dobrym głosem, jak wspominał, posługiwał się magnetofonem, by uczyć dzieci śpiewu), pielgrzymek (szczególnie tych na Jasną Górę), a także innych spotkań i wydarzeń duszpasterskich.

25 W. Dudziński, Pierwszy taki Sacrosong, „Niedziela” 2009 nr 20, s. 14.

26 S. Piotrowski, Na ringu, Kalisz 1992, s. 21. Autor nie podaje dokładnej daty organizacji tego pierwszego w diecezji włocławskiej minifestiwalu piosenki chrześcijańskiej.

27 S. Piotrowski, Na ringu, dz. cyt., s. 51-52. Ksiądz Piotrowski wspomina: „Rozśpiewał się cały Kalisz. Występy artystyczne odbywały się w różnych kościołach. Głównie w kościele Opatrzności, który choć olbrzymi, był przepełniony. Młodzież z chórów i zespołów gromadziła się na Mszy św. Jednym słowem milczący i pobożny Kalisz dał się zdobyć przez śpiewającą młodzież ze wszystkich stron Polski" (S. Piotrowski, Na ringu, dz. cyt., s. 52). 
Rozumiał, że muzyka i śpiew są jednym z najlepszych sposobów pobudzania życia wewnętrznego człowieka.

Przez całą dekadę (1978-1988) ks. Stanisław zajmował się niezwykle pracochłonną organizacją Dni Kultury Chrześcijańskiej w Kaliszu (nazywano je także Tygodniami Kultury Chrześcijańskiej). Dni Kultury, odbywające się cyklicznie przez kilkadziesiąt lat w licznych polskich miastach, były odpowiedzią Kościoła na zawłaszczenie przestrzeni publicznej przez system komunistyczny. Dzięki nim społeczeństwo miało możliwość kontaktu ze sztuką niezależną i chrześcijańską, możliwość spotkania ciekawych ludzi ze środowiska kultury, nauki, filozofii, sportu itp. Na ogół spotkania odbywały się przez kilka jesiennych niedziel w wybranych świątyniach Kalisza i koncentrowały się wokół hasła przewodniego, które korelowało z programem duszpasterskim Kościoła na dany rok. W repertuarze imprez umieszczano występy chórów, scholii i orkiestr, przedstawienia teatralne, oratoria, wykłady, wystawy, projekcje filmowe, olimpiady wiedzy religijnej itp. Do udziału w Dniach Kultury zapraszano gości z całej Polski ${ }^{28}$. Formuła spotkań dawała szanse prezentacji nie tylko profesjonalnym zespołom muzycznym i teatralnym, ale także mniejszym grupom parafialnym i środowiskowym. Dzięki temu Dni Kultury pełniły również funkcję inspiracyjną i wspólnototwórczą, wyzwalając w wielu ludziach pasję tworzenia i odkrywania piękna.

Podobne (częściowo) cele przyświecały wielu innych propozycjom sceniczno-teatralnym inspirowanym przez ks. Piotrowskiego. Już w najwcześniejszych publikacjach podkreślał nie tylko przywilej, ale wręcz obowiązek budowy kultury chrześcijańskiej, wynikający wprost z nakazu przekazanego pierwszym ludziom w raju ${ }^{29}$. Z jednej strony jako pracownik kurii odpowiedzialny w latach 50. za duszpasterstwo, uwrażliwiał kapłanów, aby troszczyli się o znakomity poziom śpiewu, architektury, malarstwa kościelnego. Z drugiej strony apelował o zapewnienie nawet

28 S. Piotrowski, Na ringu, dz. cyt., s. 31-33.

29 S. Piotrowski, Myśli do kazania na Boże Narodzenie, „Wiadomości Duszpasterskie” 1951 nr 13, s. 16 [Podp: Ks. F. Foks]. Co ciekawe, to samo źródło inspiracji i te same wnioski towarzyszyły kilka dekad później Janowi Pawłowi II w jego rozważaniach nad rolą kultury w istnieniu człowieka i świata (zob. więcej Jan Paweł II, Pamięć i tożsamość, Kraków 2005). 
małym, wiejskim parafiom możliwości prowadzenia misji nie tylko ewangelizacyjnej, ale także kulturowej ${ }^{30}$.

W kolejnych parafiach jego posługi proboszczowskiej zachowały się liczne świadectwa osobistej aktywności w zakresie popularyzacji kultury i sztuki. Wśród najczęściej stosowanych form można spotkać: inscenizacje, jasełka, misteria, akademie, deklamacje poetyckie i patriotyczne oraz spektakle popielgrzymkowe, w czasie których uczestnicy w formie scenicznej dzielili się wiedzą o poznanych sanktuariach, obiektach historycznych, o dziedzictwie duchowym i kulturowym odwiedzanych narodów ${ }^{31}$.

Ksiądz Piotrowski został mianowany w 1964 roku członkiem Komisji Episkopatu do spraw Filmu, Radia, Telewizji i Teatru. Przygotowywał referaty i wystąpienia dla środowisk w całej Polsce, proponując konkretne sposoby wykorzystania mediów w duszpasterstwie. Pisał recenzje filmowe. Doceniając rozwój nowych środków przekazu starał się zainteresować nimi także swoich wychowanków. W zapiskach wspomina, jak w pierwszej połowie lat 60. w czasie wakacji urządził dla kleryków kurs posługiwania się kamerą filmową i wspólnie z nimi nakręcił pierwszy dokument pt. Kameduli w Bieniszewie $e^{32}$. Próbował także tworzyć poradnik korzystania w domu z telewizora (być może naiwny z dzisiejszego punktu widzenia, choć nie pozbawiony przenikliwości w wykrywaniu zagrożeń, jakie niósł nowy system masowego przekazu informacji) ${ }^{33}$.

Wzajemne relacje Kościoła i kultury ciągle wydają się w licznych punktach dość rozbieżne, choć winę za to ponosi raczej ogólne rozwarstwienie i laicyzacja współczesnego społeczeństwa. Tym niemniej ks. Piotrowski nawiązując, a nawet antycypując wskazania Soboru Watykańskiego II,

30 S. Piotrowski, Duszpasterz i duszpasterstwo, t. 1, dz. cyt., s. 16-18. Ksiądz Piotrowski pisze: „Widzimy, jak wszystkie sztuki i techniki są dziś rozwijane i doprowadzone do perfekcji. I zawsze wykorzysta je taka, czy inna idea, ten lub inny kierunek polityczny. I spostrzegamy, że rozwój kin, literatury, malarstwa, mównictwa z całą gwałtownością wciągany jest w służbę kierunków antychrześcijańskich. Dlatego nowoczesny duszpasterz w ramach świątyni pielęgnuje wszystkie sztuki, uprawiane przez ludzi dzisiejszych" (S. Piotrowski, Duszpasterz i duszpasterstwo, t. 1, dz. cyt., s. 17).

31 Por. J. Stańczuk, Stanisław Piotrowski, dz. cyt., s. 179-180.

32 S. Piotrowski, W służbie, Kalisz 1998, s. 15.

33 S. Piotrowski, Kluczyk do telewizora, „Gość Niedzielny” 37 (1968) nr 29, s. 3. 
usilnie wykorzystywał możliwości kultury w służbie ewangelizacji. W rok po jego śmierci papież Jan Paweł II opublikował słynny List do artystów, w którym ponownie zaprosił do „owocnej współpracy między światem sztuki a Kościołem" ${ }^{34}$.

Tak zwana sztuka wysoka nie jest w stanie wypełnić misji ewangelizacyjnej wobec całego społeczeństwa. Z jednej strony ogranicza ją ignorancja kulturowa odbiorcy, z drugiej często sama ulega pokusie trywializowania spraw duchowych, a nawet przedstawiania ich w atmosferze skandalu i bluźnierstwa. Z tego powodu ks. Piotrowski nie lękał się popularyzować kultury masowej, choć tutaj zawsze pojawia się niebezpieczeństwo kiczu albo komercjalizacji sztuki. Odnalezienie właściwych proporcji i kierunków rozwoju zawsze będzie stanowić zadanie kolejnego pokolenia duszpasterzy.

Ksiądz Piotrowski umiejętnie wykorzystywał własną wrażliwość artystyczną, zdolności organizacyjne i osobiste znajomości ze światem kultury, aby zaprosić ten świat do służby Ewangelii. Podążając za tą intuicją, należy konsekwentnie dążyć do współpracy środowiska artystycznego i ludzi Kościoła. Jest to jedno z tych wyzwań, dla których duszpasterstwo będzie zawsze poszukiwało aktualnych rozwiązań. Idea ta pozostanie niezmienna, chociaż wydaje się coraz trudniejsza w realizacji ze względu na sekularyzowanie się oraz upadek edukacji kulturowej dzisiejszych społeczeństw.

\section{Między ubogimi}

Przy licznych obowiązkach katechetycznych, kurialnych i diecezjalnych, przy całym zaangażowaniu w świat wychowania, edukacji i kultury ks. Piotrowski nigdy nie zapomniał, że miłosierdzie wobec ubogich jest pierwszą i podstawową twarzą chrześcijaństwa. Potrzebę głoszenia tego miłosierdzia widział zarówno w osobistej postawie kapłana, jak też w zorganizowanej akcji charytatywnej w parafii czy w lokalnym

34 Jan Paweł II, List do artystów (4.04.1999), Wrocław 2005. 
środowisku ${ }^{35}$. W tekstach publicystycznych, katechetycznych i homiletycznych ten temat widoczny jest od pierwszych do ostatnich jego artykułów.

Przyczyny ubóstwa duchowego i materialnego dostrzegał w niezrozumieniu Ewangelii, w zbytniej indywidualizacji życia (także u chrześcijan), w coraz szybciej rozwijającym się konsumpcjonizmie ${ }^{36}$. Brak postawy miłosierdzia wynikał także z powodu niewłaściwego wychowania w domu i w szkole ${ }^{37}$. Prosił, by kapłani chwytali się wszelkich możliwych sposobów, aby dotrzeć z pomocą do ludzi potrzebujących. Sam zresztą dawał niesamowicie skuteczny, indywidualny przykład. Wiele osób, nawet świeckich, nie rozumiało jego wręcz mistycznego umiłowania ubóstwa. Oddawał cały dobytek, który uważał za zbędny, często posługując się jedną zaledwie parą butów i kilkoma starymi koszulami na zmianę. Jego osobisty przyjaciel, bp Kazimierz Majdański, podsumował postawę ks. Piotrowskiego w kilku wersach:

Nie było w tym stylu życia miejsca na osobiste wymagania. W mieszkaniu najskromniejszym - równie uboga odzież, z sutanną włącznie (...). Podziwiał ten styl jego dawny profesor z Włocławka, Prymas Tysiąclecia. Powiedział w rozmowie ze mną: To jest kapłański abnegat. Tajemnica więc jego kapłańskiej posługi najgłębsza, to oddanie bez reszty Boskiemu Mistrzowi i oddanie - śladami Boskiego Mistrza - człowiekowi ${ }^{38}$.

Zorganizowanie bardziej systematycznej pomocy charytatywnej odbywało się w dość zróżnicowanych warunkach politycznych i społecznych: okupacji, PRL-u, wolnej Polski. Jakimś wspólnym elementem tych zmieniających się epok była pomysłowość i spontaniczność wielu

35 S. Piotrowski, Zagadnienia duszpasterskie, dz. cyt., s. 54. Autor stwierdza: „Troska o wygodę nie może być w życiu i słowach kapłana rzucająca się w oczy. Chrystus nie wygodami odkupił człowieka. A Kościół w swoich dziełach co zrobił dobrego przez swoich pracowników, to właśnie przez zaparcie i wygody. Czy wielu jest takich kapłanów, którzy zamiast powiedzieć: mam prawo do wygody, powiedzieliby z całym wewnętrznym przekonaniem: mam prawo do niewygody. Odrodzenie parafii rozpoczyna się z chwilą rozpoczęcia walki proboszcza z wygodą w życiu osobistym, czyli z realizacją prawa do niewygody" (S. Piotrowski, Zagadnienia duszpasterskie, dz. cyt., s. 54).

36 S. Piotrowski, Miłosierdzie, „Ład Boży” 8 (1952) nr 18, s. 2.

37 S. Piotrowski, Przemówienia do dzieci o rodzinie, Kalisz 1990, s. 53.

38 K. Majdański bp, Życie jak szarża ułańska, dz. cyt., s. 118. 
inicjatyw ks. Piotrowskiego, połączona z dynamiką realizacji. W czasie wojny, ukrywając się przez dwa lata w okupowanej Warszawie, współdziałał z Radą Główną Opiekuńczą. Pełnił min. obowiązki wychowawcy internatu ${ }^{39}$. W okresie proboszczowania wykorzystywał te niewielkie obszary legalnej działalności, które pozostały do dyspozycji Kościoła po zlikwidowaniu w 1950 roku kościelnej Caritas. W parafii w Kaliszu organizował półkolonie. Założył Kaliskie Stowarzyszenie Charytatywne. Poszukiwał świeckich wolontariuszy. W okresie stanu wojennego podjął się rozdzielania pomocy materialnej z Zachodu na obszarze sześciu dekanatów. Ostatnim z wielkich dzieł miłosierdzia, już w trakcie emerytury, było zainicjowanie kuchni dla potrzebujących, która wydawała do kilkudziesięciu posiłków dziennie. Dużą część środków pozyskiwał we własnym zakresie, dokładając do funkcjonowania jadłodajni także własne uposażenie ${ }^{40}$.

Nie jest wykluczone, że właśnie ten rys działalności charytatywnej, połączony z indywidualnym wyborem ubóstwa jako opcji życia, pozostanie najdłużej i najlepiej zapamiętanym elementem posługi kapłańskiej ks. Piotrowskiego. W opublikowanej pięć lat po jego śmierci księdze pamiątkowej, zawierającej świadectwa kilkudziesięciu osób, ten temat budził wielkie zainteresowanie, a kilka osób wprost przyznało, że dzięki temu odnalazło swoje właściwe miejsce w Kościele ${ }^{41}$.

39 S. Piotrowski, Zerwane okowy..., dz. cyt., s. 117-119. Ksiądz Piotrowski pisze we wspomnieniach o działalności wychowawczej i konspiracyjnej, o tajnych kompletach i posłudze duchowej. Pośrednio wspomina o pomocy materialnej dla młodzieży i innych osób w okupowanej Warszawie.

40 J. Stańczuk, Stanisław Piotrowski, dz. cyt., s. 305-309.

41 Stużył $w$ prostocie $i$ miłości: księga pamiątkowa ku czci ks. Stanisława Piotrowskiego (1912-1998), red. S. Olejnik, J. Plota, Kalisz 2003. Celowo nie podano tutaj żadnych konkretnych stron, bowiem dopiero całościowa lektura licznych świadectw - kapłanów, sióstr zakonnych, laikatu, młodzieży itp. - pozwala ujrzeć piękno osobowości tego szlachetnego i ubogiego kapłana (przyp. aut.). 


\section{Testament duszpasterski}

Omówione powyżej inicjatywy pastoralne ks. Piotrowskiego nie wyczerpywały jeszcze pełnego zakresu jego działalności. Analizując biografię i kierunki pracy tego kapłana oraz ufając jego niezwykłej intuicji pastoralnej, należy w tym miejscu wskazać inne dziedziny duszpasterstwa, które od współczesnego Kościoła wymagają zwiększonej aktywności. Z dużą dozą pewności można wnioskować, że zmarły 20 lat temu charyzmatyczny kapłan wskazał przynajmniej dwa problemy, z którymi będzie mierzył się Kościół i społeczeństwo Europy w pierwszej połowie XXI wieku.

Pierwszym z nich jest troska o środowisko naturalne, troska wypływająca nie tylko z postulatów ekologicznych (ekonomicznych, zdrowotnych itp.), ale głównie z miłości do natury podarowanej nam przez Boga oraz z miłości do bliźniego, który jest współużytkownikiem wspólnego świata $^{42}$.

Pierwsze pisemne dokumenty na ten temat pochodzą z połowy lat 50. Powstał wówczas referat poświęcony duszpasterstwu turystów. Autor prezentował go na konferencjach dla kapłanów ${ }^{43}$. Punktem wyjścia do rozważań o potrzebie takiego duszpasterstwa było biblijne przesłanie o świecie przyrody jako naturalnej księdze objawienia Bożego. Większość inicjatyw wędrownych i obozowych dla dzieci, młodzieży i kleryków, a potem dla dorosłych pielgrzymów ks. Piotrowski łączył zawsze ze szczególnym uwrażliwieniem na piękno przyrody i z potrzebą troski o jej niezakłócony rozwój. Dbał - dla przykładu - aby piesza pielgrzymka z Kalisza do Częstochowy, za którą był przez wiele lat odpowiedzialny, zawsze wyruszała wyposażona w doskonale działające służby sanitarne, z workami na śmieci i specjalnymi namiotami toaletowymi. Edukacja społeczeństwo w kwestii porządku i czystości na kwaterach nie była łatwa. Jak sam przyznaje we wspomnieniach, niejednokrotnie osobiście

${ }^{42}$ W podobnym duchu kilka dekad później wypowiada się papież Franciszek w encyklice Laudato si'.

43 S. Piotrowski, W służbie, dz. cyt., s. 95. 
musiał tłumaczyć pielgrzymom konieczność prawidłowego zachowania ${ }^{44}$. Ta postawa miłości do przyrody, do ojczystej ziemi, do jej historii i teraźniejszości również dość często przebijała się w świadectwach złożonych po śmierci ks. Piotrowskiego ${ }^{45}$.

Innym zadaniem, które wielokrotnie wracało w jego wypowiedziach, a nasiliło się szczególnie po odzyskaniu przez Polskę suwerenności w 1989 roku była potrzeba pojednania i współpracy między zwaśnionymi narodami Europy. Już w drugiej połowie lat 60., będąc proboszczem w Kole, przyjmował delegację niemieckiej młodzieży, która pomagała w porządkowaniu obozu w Chełmnie. W latach 90 . nawiązał bardzo aktywną współpracę z niemieckim miastem Hamm. Doszło do kilku wzajemnych spotkań młodzieży i do popularyzacji wiedzy o swoich regionach i swoim stylu życia ${ }^{46}$.

Wielka fascynacja ruchem pielgrzymkowym wiązała się dla niego również z nadzieją na wzajemne poznanie się i łączenie narodów Europy.

Pielgrzymuje cała Europa (Polska, Francja, Hiszpania, Niemcy...). Świadkowie stwierdzają, że plac św. Piotra w Rzymie podczas środowych audiencji jest wypełniony po brzegi. Można dodać, że pielgrzymowanie w Europie jest jednym z elementów zjednoczenia chrześcijańskiej Europy. W pielgrzymowaniu przeważa liczbą młodzież! $!^{47}$

44 S. Piotrowski, $W$ stużbie, dz. cyt., s. 66.

45 E. Piechota, Co pamiętam?, w: Stużył w prostocie i miłości, red. S. Olejnik, J. Plota, dz. cyt., s. 258-259. Autorka wspomnienia pisze tam: „Księdza Prałata poznałam daleko na Kaszubach, gdy pełniłam funkcję wychowawcy na koloniach letnich, na Żabiance w Gdańsku-Oliwie. Ksiądz odpoczywał w Gdyni. Tak, jak my, wyjechał na Kaszuby, aby podziwiać tamtejsze pejzaże. Dołączył się do nas, wędrował z nami. Kupił wszystkim małe lody. Mówił: «Patrzcie, jakie piękne jest lato na Kaszubach z cieniami masywnych obłoków wędrujących po wzgórzach, nad polami dojrzewającymi żytem, nad zielonymi kartofliskami, nad ciemnymi lasami, nad łubinami krzyczącymi z radości. Tylko Toskania może stanąć obok tej uśmiechniętej ziemi. I jak tu nie wierzyć, że jest to ziemia Chrystusa... Piękny kaszubski świat... Dobrze, żeście tu przyjechali...». Uczył tej miłości do Polski po swojemu, bez pouczeń, nakazów. Uczył - sobą. (...). W przededniu odjazdu z kolonii zaprosiliśmy księdza Piotrowskiego na kolację i uroczyste, pożegnalne ognisko, które odbyło się na łąkach (dziś są tam ogrody działkowe) niedaleko morza. Ksiądz - harcerz i żołnierz - mówił w swej legendzie o obronie Westerplatte, o majorze Sucharskim, o walkach nad Bzurą w 1939 roku. Młodzież miała łzy w oczach (...)".

46 S. Piotrowski, W stużbie, dz. cyt., s. 106-110.

47 S. Piotrowski, Święty Józef na dziś i jutro, Kalisz 1990., s. 25 [br. aut.]. 
Jako jeden z głównych celów organizowanych przez siebie pielgrzymek zagranicznych wymieniał poznanie dziejów Kościoła w sąsiednich narodach oraz występujących tam dramatów społecznych i osiągnięć cywilizacyjnych $^{48}$.

Wypada na końcu podkreślić, że zarówno dylematy ekologiczne, jak i problem współistnienia narodów Europy (także w kontekście związków politycznych czy masowych migracji) będą dla Kościoła najbliższych lat jednym z poważniejszych wyzwań pastoralnych. Nakreślenie bowiem chrześcijańskiej wizji świata przyrody czy odpowiedzialności za politykę społeczną naszego kontynentu wymaga znalezienie szeregu konkretnych, szczegółowych rozwiązań dla Kościołów lokalnych.

\section{Podsumowanie}

Życie i twórczość ks. Stanisława Piotrowskiego są pastoralnym drogowskazem dla kapłaństwa i dla duszpasterstwa. Wiele z jego inicjatyw nie zostało, niestety, udokumentowanych ani przez niego samego, ani przez najbliższe otoczenie. Był niezwykłym opiekunem i przyjacielem młodzieży. Wzmacniał rolę rodziny. Pragnął włączać w apostolat jak największą liczbę osób świeckich. Doceniał rolę kultury i sztuki w dziele ewangelizacji. Większość pomysłów rodziła się przed Soborem Watykańskim II, stąd wniosek, że należał do grona tych profetycznych kapłanów, który dokładnie analizowali i przewidywali konieczne kierunki rozwoju Kościoła. Wśród zadań, które stawiał przed swoimi następcami były również problemy ekologiczne oraz szukanie dróg braterstwa między narodami Europy. Jego dokonaniami interesowali się kard. Stefan Wyszyński i Jan Paweł II. Jego pastoralna intuicja w połączeniu z duchem osobistego zaangażowania pozwalają widzieć w nim jednego z najwybitniejszych duszpasterzy drugiej połowy XX wieku.

48 S. Piotrowski, Z grodu św. Józefa pielgrzymka do grobu św. Piotra, Kalisz 1988, wstęp bez numeracji stron [br. aut.]. 


\section{Summary}

\section{Ksiądz Stanisław Piotrowski, apostoł Kalisza}

Ks. Stanisław Piotrowski (1912-1998) był cenionym i charyzmatycznym duszpasterzem. Jest jednym z wybitniejszych kapłanów drugiej połowy XX wieku, zaangażowanym w religijną, społeczną i kulturalną edukację młodzieży. Według jego opinii kultura powinna być silnie obecna w ewangelizacji i nauczaniu katechetycznym. Był współautorem pierwszego zintegrowanego programu przygotowania do sakramentu małżeństwa. Jest także przykładem życia osobistego opartego na wyrzeczeniu i umiłowaniu ubóstwa. Każdy, kto zajmuje się duszpasterstwem młodzieży, może znaleźć inspirację w życiu i pismach ks. Piotrowskiego.

Słowa kluczowe: ksiądz Stanisław Piotrowski, teologia, młodzież, rodzina, kultura

\section{Father Piotrowski, an apostle of Kalisz}

Fr. Stanislaw Piotrowski (1912-1998) was respected by many and was a charismatic pastor. He is one of foremost pastors of the second half of the twentieth century, his commitment being exemplary in the religious, social and cultural education of the youth. In his opinion, culture should be linked with evangelization and catechetic teaching in socjety. He was a co-author of the first integrated program of preparation in the sacrament of marriage. He also stands as an exemplar in his private life through the practice of self-denial and the virtute of poverty. Everyone who works in pastoral camps with the young can be inspired by fr. Piotrowski's life and writings.

Keywords: fr. Stanisław Piotrowski, theology, youth, family, culture

\section{Bibliografia}

Bąk J., Piotrowski Stanisław, w: Leksykon duchowieństwa represjonowanego w PRL w latach 1945-1989, t. 2, red. J. Myszor, Warszawa 2003.

Bielecki S., Znaki czasu i ich rozpoznawanie, w: Teologia pastoralna, t.1, red. R. Kamiński Lublin 2006.

Charytański J., Zmagania o kształt katechezy w Polsce. Długa wspólna droga, Kraków 2001.

Dawson Ch., Religia i kultura, J. W. Zielińska, Warszawa 1959.

Dudziński W., Pierwszy taki Sacrosong, ,Niedziela” 2009 nr 20.

Dutkiewicz B., Wartości „sacrum” a problemy ekspresji muzyczno-ruchowej, w: Sacrum - sztuka - wychowanie, red. W. A. Sacher, Kraków 2006.

Frątczak W., Diecezja włocławska w okresie II wojny światowej, Włocławek 2008. 
Jan Paweł II, List do artystów (4.04.1999), Wrocław 2005.

Majdański K. bp, Życie - jak szarża ułańska, w: Służył w prostocie i miłości: księga pamiatkowa ku czci ks. Stanisława Piotrowskiego (1912-1998), red. S. Olejnik, J. Plota, Kalisz 2003.

Maritain J., Humanizm integralny. Zagadnienia doczesne $i$ duchowe nowego świata chrześcijańskiego, Warszawa 1981.

Muszyński H. bp, Jeden z najbardziej niezwykłych ludzi, których spotkałem, w: Stużyt w prostocie imiłości: księga pamiątkowa ku czci ks. Stanisława Piotrowskiego (1912-1998), red. S. Olejnik, J. Plota, Kalisz 2003.

Piechota E., Co pamiętam?, w: Służył w prostocie i miłości: księga pamiątkowa ku czci ks. Stanisława Piotrowskiego (1912-1998), red. S. Olejnik, J. Plota, Kalisz 2003.

Piotrowski S., Duszpasterz i duszpasterstwo, t. 1-2, Włocławek 1956-1958.

Piotrowski S., Jak gotyckie katedry, w: Facere voluntatem Tuam. [Księga Jubileuszowa ku czci ks. arcybiskupa K. Majdańskiego], red. J. A. Kłys i in., Szczecin 1995.

Piotrowski S., Kluczyk do telewizora, „Gość Niedzielny” 37 (1968) nr 29.

Piotrowski S., Miłosierdzie, „Ład Boży” 8 (1952) nr 18.

Piotrowski S., Myśli do kazania na Boże Narodzenie, „Wiadomości Duszpasterskie” $1951 \mathrm{nr} 13$ [Podp: Ks. F. Foks].

Piotrowski S., Na drodze nowej ewangelizacji, wywiad z ks. Piotrowskim przeprowadziła E. Placińska, „Ład Boży” (dodatek do „Niedzieli”) 1998 nr 5, s. VII.

Piotrowski S., Na ringu, Kalisz 1992.

Piotrowski S., Poradnictwo parafialne dla małżeństw, „Ateneum Kapłańskie” 50/56 (1958) z. 2 (295), s. 248-257.

Piotrowski S., Święty Józef na dziś i na jutro, Kalisz 1990 [br. aut.].

Piotrowski S., Wandzia Brodzikowska, Włocławek 1952 [Mps ilustr. w BSWł, sygn.: M 96].

Piotrowski S., W służbie, Kalisz 1998.

Piotrowski S., Zerwane okowy, Kalisz 1998.

Piotrowski S., Z grodu św. Józefa pielgrzymka do grobu św. Piotra, Kalisz 1988 [br. aut.].

Plota J., Duszpasterz, w: Stużył w prostocie i miłości: księga pamiątkowa ku czci ks. Stanisława Piotrowskiego (1912-1998), red. S. Olejnik, J. Plota, Kalisz 2003.

Poniński A., Piotrowski Stanistaw, w: Stownik polskich teologów katolickich 1995-2003, t. 9, red. J. Mandziuk, Warszawa 2006, s. 497-500.

Rulka K., Ludwiczak J., Publikacje ks. Stanisława Piotrowskiego, w: Służył w prostocie i miłości: księga pamiątkowa ku czci ks. Stanisława Piotrowskiego (1912-1998), red. S. Olejnik, J. Plota, Kalisz 2003.

Stańczuk J., Stanisław Piotrowski. Kapłan- harcerz - wychowawca, Warszawa 2013. 